\title{
Rapid detection of hepatitis B virus DNA in liver tissue by in situ hybridisation and its combination with immunohistochemistry for simultaneous detection of $\mathrm{HBV}$ antigens
}

\author{
J Y N Lau, N V Naoumov, G J M Alexander, R Williams
}

\begin{abstract}
A rapid technique using a non-radioactive reporter molecule (digoxigenin) for intrahepatic hepatitis B virus (HBV) DNA detection using in situ hybridisation was developed. It can be adapted for use in combination with standard immunohistochemistry for simultaneous detection of both HBV DNA and HBV antigens. The total time required for dual detection of $\mathrm{HBV}$ antigens and HBV DNA starting from paraffin wax liver sections was two working days. A good signal to background ratio for the detection of HBV DNA was always obtained using this labelling. This technique is cheap, safe, and relatively simple which makes it an ideal tool for the detection of intrahepatic HBV DNA for both routine diagnostic purposes and in research.
\end{abstract}

In situ hybridisation using complementary DNA (cDNA) probes is highly sensitive for the detection and localisation of specific nucleic acid sequences in cell suspensions or tissue sections based on the formation of a highly specific hybrid between an appropriately labelled probe and its complementary sequence in the specimen. In a previous study we described the use of nonradioactive biotin labelled $\mathrm{HBV}$ DNA probe which gave a good signal but this could be affected by endogenous biotin. ${ }^{1}$ Digoxigenin, a plant steroid introduced recently as a reporter molecule for non-radioactive labelling of cDNA probes, may avoid the background encountered with biotin labelling. Here we describe a rapid and reproducible method for the detection of HBV DNA in paraffin wax embedded liver specimens with in situ hybridisation, using a digoxigenin labelled HBV DNA probe which can be adopted for use in combination with immunhistochemistry for simultaneous detection of HBV antigens in liver tissue. The use of this technique may clarify the relation between the expression of intrahepatic viral gene and the expression of viral and non-viral antigens.

Methods

Liver tissue was obtained from 16 patients with chronic HBV infection seropositive for HBsAg (13 patients were seropositive for HBeAg and three seropositive for anti-HBe) undergoing liver biopsy as part of their routine clinical management. The biopsy specimen was fixed in formol-saline solution ( $10 \%$ formaldehyde vol/vol in physiological saline solution) for 18 to 24 hours and embedded in paraffin wax for routine histological assessment. Five micrometre sections were cut and floated in warm water and mounted on slides previously coated with $2 \%$ 3-aminopropyl-1-trioxysilane (Sigma, Dorset, England). Sections were air dried vertically at room temperature, heated on a heater plate at $60^{\circ} \mathrm{C}$ for 20 minutes, and stored at room temperature.

\section{PROBES}

Full length HBV DNA (3.2 kilobase pairs) was obtained from the recombinant plasmid pBR322 (kindly donated by Professor K Murray) by restrictive digestion with XhO-I (BRL, Cambridge, England) and gel electrophoresis purification. ${ }^{2}$ A pHY2.1 Y chromosome specific probe and a probe for human DNA (prepared from human placenta) was kindly provided by Dr A Bhatt (London) and Dr F Farzaneh (London), respectively, as positive controls. A probe for Escherichia coli gene, chloramphenicol acetyltransferase (CAT), also donated by Dr F Farzaneh (London), was used as a negative control. The probes were labelled with digoxigenin-11dUTP by random priming for 16 hours using a digoxigenin DNA labelling and detection kit (Boehringer Mannheim, Mannheim, Germany) according to the manufacturer's protocol. The labelling in each case was confirmed by spotting serial dilutions of labelled probes on to Hybond-N membrane (Amersham International), fixed with ultra-violet light and detected with the immunodetection system according to the manufacturer's protocol. ${ }^{3}$ The digoxigenin-labelled probes were aliquoted and stored at $-20^{\circ} \mathrm{C}$.

\section{IMMUNOHISTOCHEMISTRY}

For simultaneous detection of $\mathrm{HBV}$ antigen and HBV DNA, HBV antigens (HBV surface antigen, $\mathrm{HBsAg}$; $\mathrm{HBV}$ core antigen, $\mathrm{HBcAg}$ ) were first sought in the liver sections by a standard indirect immunoperoxidase method. Slides were heated at $56^{\circ} \mathrm{C}$ for $10-15$ minutes, 
dewaxed in xylene briefly for only 15 seconds to maximise $\mathrm{HBV}$ antigen detection according to previous recommendations. ${ }^{45}$ The sections were then rinsed twice in alcohol for five minutes. Endogenous peroxidase activity was blocked with methanol containing $1 \%$ hydrogen peroxide for 30 minutes. Subsequently, sections were rehydrated through graded alcohol solutions and washed three times in TRIS-buffered saline (TBS) (pH 7.6). Sections were covered with $10 \%$ serum (HBsAg: rabbit, $\mathrm{HBcAg:} \mathrm{swine)} \mathrm{and}$ $3 \%$ bovine serum albumin (BSA, Sigma) in TBS for 15 minutes to block non-specific absorption. Appropriately diluted mouse monoclonal anti-HBs (donated by Drs $R$ Tedder and B Ferns) diluted 1 in 5 and rabbit polyclonal anti-HBc (Dako, High Wycombe, England) diluted 1 in 200 in $1 \%$ BSA and $1 \%$ serum in TBS were applied for 40 minutes at $37^{\circ} \mathrm{C}$. The sections were then washed with TBS and covered with appropriate peroxidase labelled second layer antibody (HBsAg: rabbit anti-mouse, dilution 1 in 50; $\mathrm{HBcAg}$ : swine anti-rabbit, dilution 1 in 50 ) in $1 \%$ BSA and $1 \%$ serum in TBS, for 30 minutes at room temperature. After further washings with TBS, the peroxidase reaction was developed with diaminobenzidine (DAB, Sigma) as substrate $\left(0.5 \mathrm{mg} / \mathrm{ml}\right.$ in TBS plus $\left.0.01 \% \mathrm{H}_{2} \mathrm{O}_{2}\right)$. The sections were then washed twice with TBS and pre-treated with freshly prepared $0.25 \%$ acetic anhydride in triethanolamine $(0.1 \mathrm{M}, \mathrm{pH} 8.0)$ for 10 minutes at room temperature to block non-specific binding to the substrate, DAB. ${ }^{16}$

\section{NON-ISOTOPIC IN SITU HYBRIDISATION}

Sections, with or without previous immunohistochemical staining for HBV antigens, were digested with protease (type XXIV, Sigma, P-8038, $11 \mathrm{IU} / \mathrm{mg}$ solid) in $50 \mathrm{mM}$ TRIS-hydrochloric acid (pH 7·4). Because this is an important step, a series of experiments were performed under various conditions (concentrations, temperature) to obtain the best specific signal with minimal proteolytic digestion to preserve morphology which was found to be $1 \mathrm{mg} / \mathrm{ml}$ protease at $37^{\circ} \mathrm{C}$ for 30 to 32 minutes. ${ }^{1}$ After proteolytic digestion slides were washed two times in glycine-PBS $(2 \mathrm{mg} / \mathrm{ml})$, five minutes each, followed by two washes with PBS. Some sections were then incubated with RNAse (R5503, $200 \mu \mathrm{g} / \mathrm{ml}$ in PBS, Sigma) and DNAse (D-5025, $300 \mu \mathrm{g} / \mathrm{ml}$ in $50 \mathrm{mM}$ TRIS-hydrochloric acid, $7 \mathrm{mM} \mathbf{M g C l}_{2}$ (pH 7.5), Sigma) for 60 minutes at $37^{\circ} \mathrm{C}$ as specificity controls. After washing with PBS, the sections were refixed with $4 \%$ paraformaldehyde (Merek; Germany) in PBS for five minutes and washed twice with glycine-PBS $(2 \mathrm{mg} / \mathrm{ml})$ five minutes each. ${ }^{78}$ This was followed by two washes with PBS, dehydrated through graded alcohol solutions and air-dried before hybridisation.

Hybridisation mixture $(10 \mu \mathrm{l})$ was applied to the liver sections. This comprised $50 \%$ formamide (Sigma) previously deionised with resin (BioRad, Hertfordshire, England), 10\% (w/v) dextran sulphate (D-6001, Sigma),
$400 \mu \mathrm{g} / \mathrm{ml}$ sheared herring sperm DNA (type XIV, D-6898, Sigma), $5 \times$ Denhardt's solution $(1 \times$ Denhardt's solution is $0.02 \%$ each of ficoll, polyvinylpyrrolidone and BSA (all from Sigma)), $2 \times$ standard saline citrate (SSC) (pH 7.0), and $0.4 \mu \mathrm{g} / \mathrm{ml}$ digoxigeninlabelled probe. Sections were then covered with a plastic coverslip and sealed. ${ }^{1}$ The tissue DNA and the probes were denatured simultaneously by incubation in a hot air oven at $95^{\circ} \mathrm{C}$ for 10 minutes and then incubated at $37^{\circ} \mathrm{C}$ for 15 to 17 hours in a humidified box. ${ }^{18}$ After hybridisation the sections were washed twice in $2 \times$ SSC for 10 minutes at room temperature, once in $2 \times$ SSC for five minutes at $60^{\circ} \mathrm{C}$, once in $0.2 \times \mathrm{SSC}$ at $60^{\circ} \mathrm{C}$ for 15 minutes and once in $0.1 \times$ SSC for $15 \mathrm{~min}$ utes at $60^{\circ} \mathrm{C}$, respectively, twice in $2 \times$ SSC for five minutes at room temperature, three times with TBS with $0 \cdot 1 \%$ Tween 20 (Sigma) for 10 minutes, and finally TBS for $10 \mathrm{~min}$ utes. These washings are essential to wash away the non-specific binding of the probes to the liver tissue.

DETECTION OF DIGOXIGENIN LABELLED PROBES The sections were covered with $5 \%$ normal goat serum and 3\% BSA in TBS at room temperature for 15 minutes to block nonspecific absorption. The blocking solution was then flipped away and covered with sheep polyclonal anti-digoxigenin antibody conjugated with alkaline phosphatase (dilution 1 in 500 in $1 \% \mathrm{BSA} / \mathrm{TBS}$ ) supplied with the kit at $37^{\circ} \mathrm{C}$ for two hours. The sections were washed four times with TBS with $0.1 \%$ Tween 20 each for 10 minutes followed by one wash with TBS alone. The substrate used were nitroblue tetrazolium and 5-bromo-4chloro-3-indoyl-phosphate(Boehringer Mannheim) in $100 \mathrm{mM}$ TRIS- $\mathrm{HCl}, 100 \mathrm{mM} \mathrm{NaCl}$, and $50 \mathrm{mM} \mathrm{MgCl}_{2}$ (pH 9.5) and the reaction was allowed to proceed for two hours. The sections were then washed with distilled water and counterstained with Kernechrot Nuclear Fast Red. Slides were dehydrated in graded alcohol solutions, cleaned in xylene, and mounted in DPX.

\section{POSITIVE AND NEGATIVE CONTROLS}

Human DNA and Y chromosome specific probes were used as positive controls and CAT probe or hybridisation mixture without probe as negative controls. Sections were also treated with RNAse and DNAse to determine the specificity of the technique. Liver sections from patients with non-HBV related disease were also studied for specificity. HBV antigens and HBV-DNA in liver tissue were also sought individually in different slides to ensure that the detection of both $\mathrm{HBV}$ antigens and HBV DNA was maximal in this dual detection technique.

\section{Results}

Liver sections remained attached to slides coated with 3-amino-propyl-1-trioxysilane after proteolytic digestion. The method for hybridisation and detection described above 


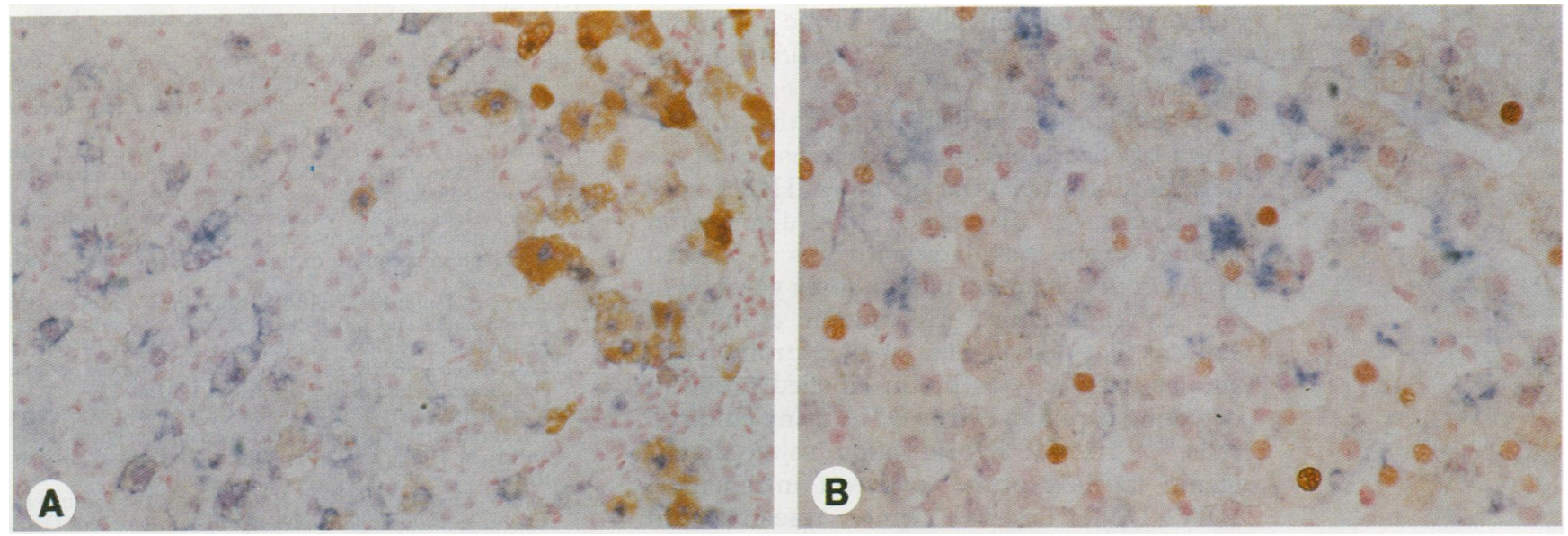

Liver section from patients with chronic $H B V$ infection showing ( $A$ ) $H B V D N A$ (blue) and $H B s A g$ (brown), and (B) $H B V$ DNA (blue) and $\mathrm{HBcAg}$ (brown). Note the apparent dissociation between the intrahepatic expression of cytoplasmic $H B V D N A$ and $H B s A g(A)$, and the absence of $H B V D N A$ in some cells with nuclear $H B c A g(B)$.

used conditions optimised in a series of experiments; it gives the best specific signal with preservation of morphology, and it was reproducible. Proteolytic digestion is the critical step in achieving this goal. In contrast to biotin labelled probe, ${ }^{1}$ background staining was usually not a major problem which is not surprising as the label, digoxigenin, is a plant steroid with no cross-reactivity with human proteins.

HBV DNA staining was seen either in nuclei of normal shape and size or more often in the cytoplasm of hepatocytes in $5-80 \%$ of the hepatocytes in the patients seropositive for HBeAg. HBV DNA was not detected in the three patients seropositive for anti-HBe. Those patients positive for cytoplasmic HBV DNA in the liver specimens were all seropositive for $\mathrm{HBeAg}$ and the staining was usually quite strong with minimal or no background. No reaction was observed with digoxigenin labelled CAT probe, when used as a negative control or when the hybridisation mixture without any probe was used. For the positive controls, $\mathrm{Y}$ bodies were visualised in almost all cells exclusively in male livers and were localised, as expected, predominantly at the periphery of the nucleus. Another positive control, the human DNA probe, also showed a strong positive reaction in every nucleus. On the other hand, there was no positive staining when the HBV DNA probe was hybridised with liver tissue from patients with non-HBV related liver disease, indicating the specificity and the low background to specific signal of this technique. RNAse pretreatment did not affect the signal whereas DNAse pretreatment abolished nearly all the detected signal, indicating that the specific signal detected in the liver tissue represents HBV DNA rather than HBV RNA.

This technique can be adopted to detect both intrahepatic HBV antigens and HBV DNA at a cellular level with good microscopic resolution (figure). $\mathrm{HBV}$ antigens ( $\mathrm{HBsAg}$ and $\mathrm{HBcAg}$ ) were sought first using the usual immunohistochemical technique and hence the detection was not affected by the subsequent procedures involved in in situ hybridisation. There was no decrease in the specific signal of $\mathrm{HBV}$ antigens after in situ hybridisation when liver sections before and after immunohistochemistry were compared. The detection for HBV DNA was also maximal using this combined immunohistochemistry and in situ hybridisation in each case, when compared with detection of HBV DNA alone in sections utilising similar techniques. In patients with both cytoplasmic $\mathrm{HBcAg}$ and HBV DNA in the same hepatocyte, the merged colour may lead to an underscoring of individual signal.

In addition to a good specific signal to background ratio, this combined procedure for immunohistochemistry and in situ hybridisation was relatively straightforward and can be completed within two working days.

\section{Discussion}

Previous studies have shown that digoxigeninlabelled HBV DNA probe is as sensitive as ${ }^{32} \mathrm{P}-$ labelled HBV DNA probe in the detection of HBV DNA in standard spot hybridisation assay. ${ }^{139}$ The present study showed that this non-radioactive digoxigenin labelled probe can also detect tissue HBV DNA with high sensitivity and specificity by in situ hybridisation. This technique also permits rapid detection and improved microscopic resolution for intrahepatic HBV DNA localisation. Furthermore, this technique can also be adopted to combine with standard immunohistochemistry for simultaneous detection of both HBV DNA and HBV antigens without loss of sensitivity for either HBV DNA or the viral antigens in paraffin wax sections.

This technique is also more convenient than using radioactive labelled probes as (1) the digoxigenin labelled probe is stable for at least two years (information from the supplier); (2) the procedures are relatively simple and straightforward without the use of radioactive isotopes; (3) a good signal to background ratio; (4) quicker (in situ hybridisation using radiolabelled probe: takes one to two weeks, compared with digoxigenin-labelled probe: within two working days); and (5) less expensive (the cost of ${ }^{35} \mathrm{~S}$-radiolabelled probe hybridisation is around 10 times more expen- 
sive than digoxigenin labelled probe hybridisation for a batch test for 50 sections in our laboratory.

Recent studies have also shown that digoxigenin labelled DNA probes were useful in the detection of other viral genomes. Heiles et al and Furuta et al showed that digoxigenin labelled probe was as sensitive as ${ }^{35}$-labelled probe in the detection of papilloma virus by in situ hybridisation. ${ }^{78}$ Herrington et al also showed that digoxigenin labelled probe had a similar sensitivity to biotin labelled probe in detecting papilloma virus DNA using cultured cells. ${ }^{1011}$ In situ hybridisation using digoxigenin labelled probe to detect intrahepatic HBV DNA deserves wider research and routine diagnostic application.

J Y N Lau was in receipt of a grant from the Croucher Foundation and N V Naoumov was supported by the Wellcome Trust.

1 Naoumov NV, Alexander GJM, Eddleston ALWF, Williams $R$. In-situ hybridisation in formalin fixed, paraffin wax embedded liver specimens: method for detecting human and viral DNA using biotinylated probes. J Clin human and viral DNA

2 Gough NM, Murray K. Expression of the hepatitis B virus surface, core and e antigen genes by stable rat and mouse cell lines. J Mol Biol 1982;162:43-67.

3 Naoumov NV, Lau JYN, Daniels HM, Alexander GJM Williams $R$. Detection of HBV DNA using a digoxigeninlabelled probe: a rapid technique without loss of sensitivity. J Hepatol 1991;12:382-5.

4 Trevisan A, Gudat F, Busachi C, Stocklin E, Bianchi L. An improved method for $\mathrm{HBcAg}$ demonstration in paraffinembedded liver tissue. Liver 1982;2:331-9.

5 Gowans EJ, Burrell CJ. Widespread presence of cytoplasmic HBcAg in hepatitis B infected liver detected by improved immunohistochemical methods. J Clin Pathol 1985; 38:393-8.

6 Sollberg S, Peltonen J, Uitto J Combined use of in-situ hybridisation and unlabelled antibody peroxidase antihybridisation and unlabelled antibody peroxidase antiperoxidase methods: simultaneous detection of type I
procollagen mRNAs and factor VIII-related antigen epitopes in Keloid tissue. Lab Invest 1991;64:125-9.

7 Heiles HBJ, Generesch E, Kessler C, Neumann R, Eggers $\mathrm{HJ}$. In-situ hybridisation of human papillomavirus (HPV $16 / 18$ ) in HeLa and SiHa cells. Biotechniques 1988;6: 978-81.

8 Furuta Y, Shinohara T, Sano K, Meguro M, Nagashima K. In-situ hybridisation with digoxigenin-labelled DNA probes for detection of viral genomes. J Clin Pathol 1990;43:806-9.

9 Buti M, Jardi R, Casacuberta JM, et al. Digoxigenin labelled DNA probes: a new non-radioactive method for hepatitis B virus DNA detection in serum. J Hepatol 1989; 9(Suppl 1):S14.

10 Herrington CS, Burns J, Graham AK, Evans M, McGee JO'D. Interphase cytogenetics using biotin and digoxigenin labelled probes I: relative sensitivity of both reporter molecules for detection of HPV 16 in CaSki cells. $J$ Clin Pathol 1989;42:592-600.

11 Herrington CS, Burns J, Graham AK, Evans M, McGee JO'D. Interphase cytogenetics using biotin and digoxigenin labelled probes II: simultaneous differential detection of human and papilloma virus nucleic acids in individual nuclei. J Clin Pathol 1989;42:601-6. 